\title{
Manajemen Pengembangan Kurikulum Seni Budaya di SD Al-Fath Bumi Serpong Damai-Tangerang
}

\author{
Agus Khumaeni' ${ }^{1}$, Susanto ${ }^{2}$ \\ ${ }^{2}$ Mahasiswa Pascasarjana Institut PTIQ Jakarta \\ ${ }^{2}$ Dosen Tetap Pascasarjana Institut PTIQ Jakarta \\ Surel: abdullahsatria81@gmail.com
}

\begin{abstract}
Abstrak
Sebagai pelajaran sangat kompetibel dengan dunia bermain anak, kurikulum Seni Budaya seharusnya dapat diimplementasikan sedemikian rupa agar dapat berdaya guna secara optimal dalam menumbuhkan kecerdasan majemuk, khusunya di tingkat sekolah dasar. Namun dalam realitanya, pelajaran seni justru masih sering dipandang "sebelah mata" sehingga berakibat pada pelaksanaan yang kurang maksimal. Sekolah SD Al-Fath yang berlokasi di Jl. Lengkong Gudang timur-BSD-Tangerang, mengembangkan kurikulum seni budaya ke dalam bentuk kelas penjurusan. selain merupakan praktik baik yang amat jarang ditemukan, upaya tersebut juga membuahkan hasil yang positif yakni tumbuhkan antusisame siswa serta kepuasan masyarakat terhadap sekolah tersebut. Namun, seiring berjalannya waktu dan dinamika pendidikan yang terus berkembang ditemukanlah hal-hal; problem yang mengakibatkan kurang optimalnya pembelajaran seni di kelas penjurusan. Penelitian ini bertujuan untuk mengetahui bagaimana pengembangan kurikulum pembelajaran Seni Budaya itu dilaksanakan di SD Al-Fath-BSD dan melihatnya dari perspektif manajemen pengembangan kurikulum. Jenis penelitian ini adalah penelitian lapangan (Field Research). Teknik pengumpulan data dalam penelitian ini yaitu: Observasi, Wawancara, dan dokumentasi. Kemudian analisis data menggunakan model Miles dan Huberman. Hasil penelitian menunjukkan bahwa manajemen pengembangan kurikulum telah dilakukan dengan baik akan tetapi masih membutuhkan upaya perbaikan agar tujuan yang diharapkan dapat terealisasi dan menuai hasil yang maksimal.
\end{abstract}

Kata Kunci: manajemen, pengembangan kurikulum, seni budaya

\begin{abstract}
As a lesson that is very compatible with the world of children's play, the Cultural Arts curriculum should be implemented in such a way so that it can be optimally useful in fostering multiple intelligences, especially at the elementary school level. However, in reality, art lessons are still often underestimated, resulting in less than optimal implementation. Al-Fath Elementary School which is located on Jl. Lengkong Gudang timur-BSD-Tangerang, developing an arts and culture curriculum in the form of majors classes. Apart from being a very rare good practice, these efforts have also yielded positive results, namely the growth of student enthusiasm and community satisfaction with the school. However, over time and the dynamics of education that continue to develop things are discovered; a problem that results in less than optimal art learning in the majors class. This study aims to determine how the development of the Cultural Arts learning curriculum is implemented at SD Al-Fath-BSD and see it from the perspective of curriculum development management. This type of research is field research. Data collection techniques in this study are: observation, interview, and documentation. Then the data analysis used Miles and Huberman's model. The results showed that the management of
\end{abstract}


curriculum development has been carried out well but requires improvement efforts so that the expected goals can be realized and reap maximum results.

Keywords : management, curriculum development, cultural arts.

\section{A. PENDAHULUAN}

Pendidikan adalah instrumen utama, salah satu kunci yang sangat esensial ${ }^{1}$ dalam pembangunan sebuah bangsa. Dalam konteks persaingan global, pendidikan merupakan gerbang utama menuju kemenangan dan kejayaan sebuah bangsa sekaligus merupakan palang pintu terakhir yang dapat membentengi generasi muda dari dampak negatif globalisasi karena dalam era global keunggulan sebuah bangsa tidak bisa lagi diukur hanya dengan mengandalkan sumber daya alamnya saja, akan tetapi juga harus dibarengi dengan keunggulan sumber daya manusianya, bahkan kualitas sumber daya manusia menempati kedudukan lebih penting dibanding dengan sumber daya alam $(\mathrm{SDA})^{2}$. kualitas SDM ditentukan oleh kualitas hasil pendidikannya, oleh karena begitu strategisnya kedudukan pendidikan bagi sebuah bangsa, ia selalu dijadikan variabl, instrumen utama dalam pembangunan bangsa di semua negara.

Dewasa ini dunia pendidikan telah memasuki babak baru, hal tersebut ditandai dengan adanya tantangan-tantangan yang lebih kompleks dari sebelumnya sehingga pemangku kebijakan pendidikan di tingkat nasional mengganti kurikulum 2006 dan memberlakukan kurikulum 2013 sebagai kurikulum yang diyakini akan lebih mampu merespon aneka perubahan dan tantangan zaman era revolusi industri 4.0 sekarang ini, meskipun di saat yang sama dunia pendidikan masih menyimpan segudang problematikanya sendiri. Termasuk problematika dalam dunia pendidikan yang tak kunjung tuntas terselesaikan sampai hari ini dan menarik perhatian penulis adalah persoalan pendidikan seni.

Dari hasil wawancara yang penulis lakukan dengan sejumulah guru seni di beberapa daerah dengan menanyakan bagaimana pembelajaran seni di sekolah guru tersebut, sebagian guru menjawab pelajaran seni yang diajarkan hanya satu jenis kesenian oleh satu orang guru, yang lain menjawab dua jenis kesenian oleh satu guru, yang lain menjawab tiga jenis oleh satu atau tiga orang guru dan pembelajaran diselenggarakan berdasarkan kemampuan guru yang ada, teacher oriented, bukan berdasarkan pada kebutuhan atau minat peserta didik. Di lokasi yang berbeda, pembelajaran seni di tingkat sekolah dasar tidak berjalan sesuai tuntutan kurikulum. ${ }^{3}$ Hal tersebut diperoleh berdasarkan wawancara yang dilakukan dibeberapa tahap dan angkatan PLPG. dari beberapa guru yang diwawancarai memberikan informasi yang beragam terkait pelaksanaan pembelajaran seni di beberapa sekolah. Saat ditanyai apakah Anda/di sekolah Anda mengajarkan pembelajaran seni? Mereka ada yang

\footnotetext{
${ }^{1}$ Ahmad Zain Sarnoto, "Paradigma Pendidikan Humanistik Dalam Pendidikan Berbasis Al Quran," Jurnal MADANI Institute Volume 7 N (2018): 101.

${ }^{2}$ Ahmad Zain Sarnoto, "Sumber Daya Manusia Dalam Pendidikan Islam," Jurnal MADANI Institute Volume 6 N (2017): 9.

${ }^{3}$ Soengkowo Soetopo, "Pendidikan Seni Di Sekolah Dasar," Jurnal Inovasi Sekolah Dasar, Vol. 2, No (2015).
} 
menjawab iya dan ada yang menjawab tidak. Yang menjawab iya, mengemukakakan bahwa cara mereka mengajarkan seni di sekolah yaitu dengan cara menggunakan buku pegangan, berdasarkan pengalaman, ada guru khusus, dan kegiatan ekstrakulikuler. Dan yang menjawab tidak mereka beralasan karena: tidak bisa, tidak berbakat, anakanak tidak tertarik, tidak ada pengalaman, tidak ada pelatihan dan tidak ada dukungan dari sekolah. Artinya pembelajaran seni di sekolah memang belum berjalan sebagaimana yang diharapkan.

Masalah pendidikan seni, khususnya di tingkat sekolah dasar amat beragam yang secara umum dapat diklasifikasikan kepada dua hal sebagai berikut.

Pertama, masalah yang berkaiatan dengan kurangnya pemahaman dan kesadaran akan pentingnya pendidikan seni. Tak dapat dipungkiri lagi bahwa pendidikan kesenian memiliki manfaat yang sangat besar bagi pertumbuhan mental peserta didik. Hal ini sebagaimana pendapat beberapa tokoh bahwa pendididikan seni dapat meningkatkan daya kreativitas anak (Dewey, Read, dan Ross); dapat digunakan sebagai sarana terapi/kesehatan mental (Margaret Numberg); dapat menghaluskan perasaan (Suwardi Suryaningrat/ Ki Hajar Dewantara); membantu pertumbuhan mental dan kreativitas anak didik (Lowenfeld); dapat mengembangkan imajinasi, kreativitas, dan kemampuan artistik serta intelektual (Kaufman); pembelajaran seni di sekolah dapat membina pertumbuhan dan perkembangan kepribadian anak didik (Wickizer); dapat dijadikan sebagai wahana memenuhi kebutuhan emosional, ekspresi, pengembangan imajinasi serta sensitivitas, dan sebagainya (Yuanita); dan lain sebagainya ${ }^{4}$. Kamaril, menyebutkan ada 3 sifat yang melekat dalam pembelajaran kesenian sebagaimana dikutip oleh purwati ningsih ${ }^{5}$, yakni sifat multidimensional dan multilingual, serta multicultural.

Selain menurut para pakar di atas, ada dua aspek lain yang turut melandasi pentingnya pendidikan seni di Indonesia yaitu

1. Aspek pendidikan kebudayaan yang terkandung dalam pembelajaran seni budaya. Kebudayaan, meskipun tidak secara eksplisit dipelajari dalam pembelajaran seni budaya, sangat bermanfaat baik bagi peserta didik itu sendiri sebagai individu yang hidup di tengah masyarakat maupun bagi upaya pelestarian dan estafet budaya bangsa. Dengan menanamkan, mengenalkan kebudayaan terhadap peserta didik, pendidik sebenarnya tengah berperan dalam menanamkan watak, mengenalkan identitas dan jatidiri sehingga dengan itu peserta didik dapat dengan mudah menyeleksi segala pengaruh yang datang dari luar, mampu memilah mana yang baik dan berguna bagi dirinya menjadi manusia yang punya pendirian, kemandirian, berbudaya dan tidak hanyut dalam bah arus globalisasi ini. Lev Vygotsky, psikolog Rusia, mengatakan bahwa diperlukan sebuah pembinaan watak dari sedini mungkin agar secara bertahap anak dapat memiliki unsur-unsur budaya yang sesuai dengan tradisi dan lingkungannya dengan demikian ia tidak tercerabut dan tidak tumbuh

\footnotetext{
4 Purwatiningsih, “Sumber Belajar Penunjang PLPG 2007 Mata Pelajaran Seni Budaya,” 2017, $5 .$.

5 Purwatiningsih, 13.
} 
menjadi seorang globalize, yakni warga dunia tanpa jiwa. ${ }^{6}$ Fenomena yang jamak terjadi di masyarakat kita sekarang menunjukkan bahwa sebagian generasi muda telah jauh meninggalkan budaya bangsanya sendiri. Mereka malu menggunakan budaya, kesenian, bahasanya sendiri dan lebih silau dengan budaya luar. Naifnya sebagian mereka mengikuti budaya asing itu tanpa berfikir atau menelaah lebih dalam mengenai apa dampak baik dan buruknya. Padahal tak jarang, banyak, budaya asing yang tidak sesuai dan bertentangan dengan nilai luhur, norma agama, serta karakter budaya bangsa Indonesia. Jika hal itu terus terjadi secara masif dan dibiarkan tanpa kendali, bukan tidak mungkin kita akan menjadi bangsa yang kehilangan karakternya. Disinilah pentingnya upaya estafet budaya bangsa sebab bangsa yang berkarakter adalah bangsa yang menghargai budayanya sendiri. ${ }^{7}$

2. Tuntutan zaman akan hadirnya generasi yang kreatif dan mempunyai keseimbangan antara sikap, pengetahuan, dan keterampilan. Selain aspek kebudayaan, Pendidikan kesenian juga memuat pendidikan prakarya yang berkenaan secara langsung dengan pemberdayaan kreativitas siswa, oleh karena itu, meskipun seni budaya bukan satu satunya pembelajaran yang berkenaan dengan akal kreatif, merefitalisasi pendidikan kesenian merupakan sebuah keharusan dan kebutuhan mendesak. Sebab dewasa ini minimnya kreatifitas anak bangsa menjadi sorotan yang serius. Di dunia industri terjadi distrupsi berskala massif, PHK terjadi di mana-mana, lowongan kerja sangat susah dicari, belum lagi hantaman wabah pandemi virus Corona yang melanda diseluruh dunia yang melumpuhkan segala sektor real kehidupan tak terkecuali sektor pendidikan di Indonesia dan hanya orang-orang kreatiflah yang mampu tampil dengan karya-karyanya dan menjadi roda penggerak kehidupan hingga menyedot lapangan pekerjaan. Hal ini sudah semestinya menjadi pelajaran yang sangat berharga dan harus direspon dengan cepat oleh dunia pendidikan; dimana sudah seharusnya pendidikan meninggalkan paradigma-paradigma usang yang sudah tidak selaras dengan tuntutan zaman dan bergegas membuka diri untuk menjadi "sekolanya manusia", yang mampu melahirkan manusia seutuhnya, manusia kreatif yang berdaya guna sesuai kecenderungan, bakat dan fitrahnya yang dapat menciptakan dan memimpin perubahan-perubahan dimasa yang akan datang dengan inovasi-inovasi yang akan mereka temukan. Maria Montessori sebagaimana yang dikutip hernawati mengatakan.

"Education should no longer be mostly imparting of knowledge, but must take a new path, seeking the release of human potentialities". ${ }^{8}$

\footnotetext{
${ }^{6}$ H.A.R Tilaar, Pengembangan Kreativitas Dan Entrepreneurship Dalam Pendidikan Nasional (Jakarta: PT Kompas Media Nusantara, 2012), 37.

7 "Pidato Kenegaraan Menteri Pendidian Dan Kebudayaan Republik Indonesia" (n.d.), https://www.kemdikbud.go.id/main/blog/2019/08/pidato-mendikbud-pada-peringatan-hut-ke74-republikindonesia.

${ }^{8}$ Hernawaty, Metode Montessori, Pendidikan Karakter Yang Mengembangkan Potensi Anak (Surabaya: Garuda Mas Sejahtera, 2015), 65.
} 
Kedua, masalah berkaitan dengan teknis pelaksanaan di lapangan. Di ranah teknis pelaksanaan, pelaksanaan kurikulum seni budaya di sekolah-sekolah tingkat sekolah dasar yang penulis himpun menemukan fakta-fakta yang amat beragam yang secara umum dapat dijelaskan sebagai berikut:

1. Pengurangan jam pembelajaran seni, di beberapa sekolah jam pembelajaran seni budaya terkadang diganti dengan pembelajaran lain yang dianggap lebih penting.

2. Mayoritas/banyak guru-guru seni di sekolah bukan berasal dari lulusan sarjana pendidikan seni bahkan tidak sedikit yang tidak memiliki kompetensi akademis di bidang seni serta pedagogi.

3. Fasilitas pembelajaran seni budaya di beberapa sekolah terbilang minim.

4. Perbedaan minat dan bakat para siswa di bidang kesenian tentu beragam namun pembelajaran seni justru sering dilaksanakan dengan mempelajari satu atau dua jenis kesenian tertentu.

Keempat fakta di atas masih jamak terjadi di dunia pendidikan kita, meskipun tidak lantas kita menafikan bahwa pembelajaran seni kurikulum 2013 dinilai sudah lebih baik dari sebelumnya, yang disadari atau tidak telah menumbuhkan stigma negatif yang menggema di alam pemikiran masyarakat bahwa pembelajaran seni budaya hanyalah pembelajaran tambahan yang tidak terlalu penting, atau tidak berada pada level yang sama dengan pelajaran lainnya. Dari sini juga dapat dipahami bahwa umumnya masyarakat masih terbawa arus post-scientific yang menganggap pelajaran Sains lebih penting dari pelajaran lainnya sehingga pada situasi tertentu jam pembelajaran kesenian dapat dengan mudah dikurangi, digeser atau ditiadakan jika pelajaran lain membutuhkan tambahan waktu belajar. padahal jika kita kembali kepada teori di atas, Seni Budaya memiliki keistimewaannya sendiri dan sama pentingnya dengan mata pelajaran lain.

Curriculum is the hearth of education, jantung pendidikan adalah kurikulum. ${ }^{9}$ Kurikulum adalah tempat di mana seluruh aktivitas pendidikan dimulai dan dikendalikan. Kurikulum memberikan dasar-dasar dan prinsip bagi pengembangan kepribadian dan kemampuan peserta didik yang selanjutnya akan menentukan bagaimana kualitas sumber daya manusia sebuah bangsa oleh karena itu jika akan memperbaiki pendidikan berarti dengan cara memperbaiki, mengembangkan kurikulumnya.

Pengembangan kurikulum adalah proses perencanaan kurikulum agar menghasilkan rencana kurikulum yang luas dan spesifik. Hal ini berkaitan dengan seleksi dan pengorganisasian berbagai komponen situasi mengajar ,belajar melalui serangkaian kegiatan. Oemar Hamalik berpendapat bahwa untuk dapat mengembangkan kurikululkum sekaligus efektif dalam pelaksanaannya dibutuhkan sebuah manajemen yang baik sebab pelaksanaan pengembangan sendiri sebetulnya mengikuti pola pikir yang singkron dengan kerangka/pola pikir manajemen, yaitu

9 Zainal Arifin, Pengembangan Manajemen Mutu Kurikulum Pendidikan Islam (Bandung: Remaja Rosdakarya, 2012), 84. 
bahwa implementasi pengembangan kurikulum harus dimulai dengan menggunakan fungsi-fungsi manajemen berupa perencanaan, pengorganisasian, pelaksanan, pengawasan yang pada ahirnya kemampuan seorang manajerlah yang memiliki peran sangat dalam menentukan berhasil atau tidaknya pelaksanaan manajemen pengembangan kurikulum tersebut. ${ }^{10}$

Di antara pihak yang turut serta dalam menaggulangi persoalan ini, khususnya di tingkat lembaga/sekolahan adalah SD Al-Fath-BSD. Sekolah tersebut mengembangkan kurikulum seni budaya dengan konsep Kelas Penjurusan Seni di mana siswa di sekolah tersebut yakni kelas IV hingga kelas VI belajar kesenian sesuai kelas penjurusan yang sudah disediakan sehingga para siswa dapat belajar secara lebih mendalam mengenai jenis kesenian yang mereka minati. Sekolah Al-Fath-BSD diketahui telah melaksanakan program penjurusan seni sejak tahun 2013. Program kelas kelas penjurusan ini merupakan inisiatif para guru (grass roots) yang dilaksanakan dengan asumsi bahwa setiap anak memiliki kecenderungan menyukai bidang kesenian yang berbeda-beda antara satu siswa dan siswa yang lain. Namun seiring berjalannya waktu, pengembangan kurikulum yang sudah mendapatkan apresiasi baik dari masyarakat harus diwarnai oleh fenomena-fenomena yang kontradiktif antara realitas dengan harapan para pengembang, hal tersebut diakibatkan oleh implementasi manajemen pengembangan kurikulum yang belum dilakukan secara optimal.

Berdasarkan latar belakang di atas, masalah pokok penelitian adalah bagaimana manajemen pengembangan kurikulum seni budaya ini dilakukan di SD Al-Fath. Yang kemudian penulis tuangkan kedalam pertanyaan-pertanyaan sebagai berikut.

1. Apa landasan pengembangan kurikulum sehingga pembelajaran seni dibuat dalam bentuk/format kelas penjurusan?

2. Komponen apa saja yang dikembangkan?

3. Ada berapa kelas penjurusan?

4. Sarana dan prasarana apa saja yang dibutuhkan dalam rangka pelaksanaan kelas penjurusan?

5. Kendala dan tantangan apa sajakah yang dihadapi dalam pelaksanaan kelas penjurusan tersebut?

Pertanyaan-pertanyaan tersebut kemudian penulis rangkum menjadi sebuah pertanyaan yang sekaligus menjadi rumusan masalah pokok pada penelitian ini yaitu, bagaimana manajemen pengembangan kurikulum Seni Budaya itu dilaksanakan di SD Al-Fath-BSD.

Pembahasan mengenai manajemen kurikulum sudah banyak dilakukan oleh pakar-pakar pendidikan. Akan tetapi, pembahasan tentang manajemen pengembangan kurikulum sekolah dasar masih terbilang sedikit. Ada beberapa penelitian yang dilakukan di beberapa perguruan tinggi di Indonesia. Dalam bentuk tesis karya Siti Subarkah yang berjudul Manajemen Pengembangan Kurikulum Sekolah Menengah

\footnotetext{
${ }^{10}$ Oemar Hamalik, Dasar-Dasar Pengembangan Kurikulum (Bandung: Remaja Rosdakarya, 2013), 24.
} 
Pertama (SMP) Alam Al-Aqwiya-Cilongok-Banyumas. Dalam tesis tersebut dibahas menajemen pengembangan kurikulum tingkat istitusi atau lembaga pendidikan dimana pengembangan kurikulum tersebut dilatarbelakangi karakter sekolah yang notabenenya di bawah naungan sebuah yayasan yang juga mengelola sebuah pesantren sehingga mempunyai religiusitas yang cukup tinggi serta pimpinan yayasan yang menginginkan lulusan sekolah tersebut memenuhi beberapa kriteria salah satunya yakni mempu membaca kitab kuning.

Referensi yang digunakan dalam tesis tersebut dan juga referensi yang digunakan oleh penulis dalam penelitian ini secara kebetulan banyak kemiripan. Hal tersebut dikarenakan tulisan ini dan tesis karya Subarkah memiliki beberapa variabel yang sama hal tersebut terlihat dalam pengambilan judul yang sama-sama mengangkat tema Manajemen-Pengembangan-Kurikulum sementara buku rujukan yang membahas mengenai hal itu tergolong terbatas. Hal tersebut menjadikan penulis tak bisa mengelak dari teori yang telah digunakan oleh tesis Subarkah yang secara kebertulan ditulis lebih dahulu.

Tesis Evi Herawati yang berjudul Pengembangan Kurikulum Pendidikan Agama Islam di Sekolah Alam (Studi Kasus di School of Universe). Dalam tesis ini membahas tentang pembahuruan yang dilakukan school of Universe adalah mengembangkan kurikulum. Penekanan pengembangan kurikulum terletak pada: pertama, materi pembelajaran yang dikaitkan dengan kehidupan sehari-hari siswa (kontestual). Kedua, metode pembelajaran yang mengutamakan praktek dan pengalaman. Ketiga, evaluasi pembelajaran yang berbasis proses. ${ }^{11}$ Penelitian tersebut memiliki kesamaan dengan penelitian yang akan dilakukan oleh penulis yaitu pada pengembangan kurikulum sekolah alam. Akan tetapi perbedaannya dalm tesis Evi Herawati lebih fokus pada mata pelajaran secara umum ditingkat lembaga sedangkan pada penelitian ini lebih fokus pada manajemen pengembangan kurikulum mata pelajaran.

\section{B. METODE PENELITIAN}

Penelitian ini menggunakan gunakan penelitian jenis kualitatif dengan tujuan untuk menggali secara mendalam serta menjelaskan fenomena atau fakta yang terjadi di lapangan. sehingga data primer penelitian ini berupa data yang benar dan faktual ${ }^{12}$ yang berkaitan langsung dengan manajemen pengembangan kurikulum seni budaya di sekolah SD-Al-Fath-BSD sedangkan data sekunder berupa dokumentasi-dokumentasi yang penulis kumpulkan dari sumber utama. Sumber data tersebut berasal dari Kepala SD Al-Fath-BSD, Koordinator Program Penjurusan Seni, dan guru-guru Seni Budaya. Dalam penelitian ini digunakan pula metode pengumpulan data/input data dilakukan pada natural setting (kondisi yang alamiah), sumber data primer dan teknik

11 Evi Herawati, "Hamalik, Oemar. Dasar-Dasar Pengembangan Kurikulum.Bandung: PT. Remaja Rosdakarya, 2013. Herawati, Evi. "Pengembangan Kurikulum Pendidikan Agama Islam Di Sekolah Alam Studi Kasus Di School of Universe" (UIN Syarif Hidayatullah, 2009), 5.

12 Suharsimi Arikunto, Prosedur Penelitian Suatu Pendekatan Praktik (Jakarta: Rineka Cipta, 2013), 129. 
pengumpulan data lebih banyak pada observasi, wawancara mendalam, dan dokumentasi. ${ }^{13}$ Data yang diperoleh selanjutnya dikumpulkan dan diadakan proses pencarian dan penyusunan secara sistematis (analisis data) dengan cara mengorganisasikan data ke dalam kategori dan menjabarkan ke dalam unit-unit, melakukan sintesa, menyusun ke dalam pola, memilih mana yang penting dan yang akan dipelajari, dan membuat kesimpulan sehingga mudah dipahami oleh diri sendiri maupun orang lain. ${ }^{14}$

\section{HASIL DAN PEMBAHASAN}

Al-Fath Primary Islamic Boarding School BSD adalah sekolah dasar yang terletak di jalan Lengkong gudang timur-Bumi Serpong Damai (BSD) Tangerang. Sekolah ini mengusung slogan "Sekolah Dwi Bahasa Berwawasan Islami". Sekolah yang menggunakan metode active learning sebagai salah satu metode unggulannya ini didirikan di bawah naungan yayasan Al-Fath Bina Insan Sakina. Pada awalnya, yayasan mendirikan sekolah dasar SD Al-Fath pertama di jalan Cirendeu Raya, Ciputat pada tahun 2001 dan dalam kiprahnya sekolah ini ternyata mampu eksis serta telah beberapa kali meluluskan peserta didiknya sehingga para pendiri merasa yakin bahwa metode pembelajaran yang digunakan itu tenyata mampu menarik minat masyarakat dan menjadikan Al-Fath mampu bersaing dengan sekolah-sekolah lainnya. Hingga pada tahun 2007 yayasan memutuskan untuk mendirikan sekolah SD Al-Fath BSD. Dengan demikian maka SD Al-Fath-BSD menggunakan kurikulum dan metode yang sama dengan SD Al-Fath di Cirendeu.

\section{Visi dan Misi Sekolah Dasar Al-Fath -BSD}

1. Visi

Membentuk generasi yang Mandiri, Kreatif, Inovatif, Berakhlakul Karimah dan Berbudaya.

2. Misi

a. Menanamkan IMTAQ melalui pengalaman dan pembelajaran islam

b. Menanamkan perilaku dan sikap sopan, toleransi dan saling menghormati seluruh warga sekolah sebagai cermin dari aklak mulia.

c. Membina kemandirian siswa melalui kegiatan pembinaan dan pengembangan diri yang terencana.

d. Menciptakan suasana belajar yang menyenangkan, aktif, kreatif, dan inovatif, dengan memperhatikan potensi yang dimiliki siswa.

Berdasarkan data yang penulis peroleh dari dokumen bank data di SD Al-FathBSD per Oktober 2020 diperoleh informasi bahwa jumlah keseluruhan peserta didik yakni 562 siswa. Dengan rincian siswa laki laki 272 dan siswa perempuan berjumlah 290.

13 Sugiyono, Metodologi Penelitian Pendidikan Pendekatan Kuantitatif, Kualitatif, Dan R\&D, Kelima (Bandung: Alfabeta, 2008), 309.

14 Sugiyono, 335. 


\section{Pembelajaran Seni di SD Alfath-BSD}

1. Kurikulum Seni Budaya sebelum dikembangkan.

Sebelum kurikulum seni budaya dikembangkan, Berdasarkan pengamatan dan interviu penulis dengan beberapa guru di SD Al-Fath-BSD diperoleh informasi bahwa pembelajaran seni khususnya di kelas IV,V dan VI di SD Al-Fath-BSD adalah sebagai berikut:

a. Pelajaran seni terdiri dari 2 bidang seni yakni Seni musik dan seni rupa.

b. Seni musik di ajarkan oleh 2 orang guru musik sementara seni art di ajarkan oleh guru di kelas masing-masing.

c. Pelajaran seni musik meliputi bernyanyi, pianika, angklung, suling recorder. Adapun seni rupa disemua kelas diajarkan tentang menggambar, meawarnai, membuat kerajianan kolase, mozaik dls.

d. Jumlah jam mengajar seni musik dalam seminggu adalah 2 jam pelajaran. Semntara untuk seni rupa 1 jam pelajaran.

e. Kompetensi dasar pelajaran seni musk dan seni rupa di ambil dari buku pelajaran seni.

f. Teknis evaluasi /penilaian menggunakan tugas individu berupa peragaan keterampilan, potofolio, esai dan lain sebagainya. ${ }^{15}$

2. Kurikulum Seni Budaya setelah dikembangkan.

Pengembangan kurikulum merupakan sebuah proses perencanaan kurikulum yang dimaksudkan untuk menghasilkan rencana kurikulum yang luas dan spesifik. Dinn Wahyudin dalam bukunya Manajemen Kurikulum menyebutkan bahwa pengembangan kurikulum pada hakikatnya adalah pengembangan komponenkomponen yang membentuk sistem kurikulum itu sendiri yang terdiri dari empat komponen utama yaitu komponen tujuan, isi kurikulum metode atau strategi pencapaian tujuan dan komponen evaluasi. ${ }^{16}$ Sukmadinata, berpandangan bahwa pengembangan kurikulum bisa berarti menyempurnakan kurikulum yang telah ada (curriculum improvement) atau bahkan menyusunan kurikulum yang sama sekali baru (curikulum contrucion) dan pada prosesnya pengembangan kurikulum berarti menyusun seluruh perangkat kurikulum mulai dari dasar dasar kurikulum, struktur dan sebaran mata pelajaran, garis-garis besar program pengajaran, sampai dengan pedoman-pedoman pelaksanaan. ${ }^{17}$ Selanjutnya, Lismina dalam bukunya Pengembangan Kurikulum, menyimpulkan bahwa diantara para ahli dan pelaksana kurikulum pendidikan belum memiliki kesepakatan dalam mengartikan kata "Pengembangan" yang terdapat dalam pengertian pengembangan kurikulum. Sebagian berpendapat bahwa jika berbicara tentang pengembangan tentu sudah ada

15 Wawancara dengan guru seni musik, Mr. Mustaqim dan Mis Ayu Dwi Retno.

${ }^{16}$ Dinn Wahyudin, Manajemen Kurikulum (Bandung: Remaja Rosdakarya, 2014), 46.

17 Nana Syaodih Sukmadinata, Pengembangan Kurikulum: Teori Dan Praktik (Bandung: Remaja Rosdakarya, 2006), 183. 
modal yang akan dikembangkan namun, sebagian yang lain mengatakan bahwa pengembangan dapat dimulai dari yang tidak ada; berarti mulai dari mengadakan baru lalu secara bertahap menyempurnakannya melalui evaluasi, revisi, evaluasi lagi, revisi lagi dan seterusnya sampai sesuai dengan harapan. Tampaknya sebagian besar ahli kurikulum justru cenderung kepemahaman yang kedua ini. ${ }^{18}$

Pengembangan kurikulum Seni Budaya di SD Al-FATH-BSD mengikuti pola pengembangan (curikulum contrucion). yakni menyusun kurikulum yang sama sekali baru (dalam format penjurusan seni) yang bertujuan untuk menyempurnakan namun tidak mengubah, tetap melaksanakan kurikulum seni budaya kurikulum 2013. Adapun tahapan yang dilakukan dalam proses pengembangan kurikulum adalah sebagai berikut: ${ }^{19}$

a. Perencanaan, analisis kebutuhan sampai dengan penyiapan dokumen-dokumen kurikulum.

b. Implementasi, rintisan dalam skala kecil sampai dengan penyebaran dalam skala besar.

c. Evaluasi, penilaian dalam keperluan perbaikan dan perubahan kurikulum.

Setelah dilakukan pengembangan kurikulum seni, dapat dijelaskan bahwa selain melaksanakan kurikulum Seni Budaya kurikulum pemerintah, SD Al-Fath juga melaksanakan program kelas penjurusan seni. Kelas penjurusan seni, adalah kelas intrakulikuler, di mana peserta didik dan tenaga pendidiknya (siswa dan gurunya) dikelompokkan, berdasarkan bidang kesenian tertentu untuk mempelajari kesenian tersebut dari sisi skillnya keterampilannya, diselenggarakan di luar pelajaran Seni Budaya kurikulum pemerintah, mulai dari kelas IV hingga kelas VI SD, dengan tujuan mewadahi dan memberdayakan potensi peserta didik dibidang seni yang beragam.

Kelas penjurusan seni budaya meliputi beberapa kelas yakni;

a. Kelas penjurusan Gitar

b. Kelas penjurusan Keyboard

c. Kelas penjurusan Gamelan

d. Kelas penjurusan Biola

e. Kelas penjurusan Choir/Paduan suara

f. Kelas penjurusan Tari/Traditional dance

g. Kelas penjurusan Visual Art

h. Kelas penjurusan Teater.

Kelas penjurusan seni dilaksanakan 2 jam pelajaran dalam 1 minggu. Di akhir tahun, para siswa kelas penjurusan akan mementaskan kebolehanya di acara-acara seperti Big Concert atau Pentas Akhir Tahun yang disaksikan orang tua, wali murid. Selain beberapa hal yang telah disebutkan di atas, penulis, melalui observasi

${ }^{18}$ Lismina, Pengembangan Kurikulum (Ponorogo: Uwais Inspirasi Indonesia, 2017), 11.

19 Rudi Susilana, Bahan Ajar Konsep Kurikulum (Bandung: Tim Jurusan Kurikulum dan Teknologi Pendidikan FIP-UPI, n.d.). 
langsung di lapangan dan wawancara menemukan beberapa fakta yang penulis simpulkan ke dalam poin-poin berikut ini.

\section{Pengembangan kurikulum Seni Budaya di SD Al-Fath dalam format kelas penjurusan, telah memiliki landasan yang kuat.}

Pengembangan kurikulum harus mempunyai landasan yang kuat yang terdiri dari empat landasan yaitu: Landasan filsafat, psikologis, Sosio-budaya, ilmu pengetahuan dan teknologi. Sesuai dengan observasi dan wawancara penulis dapat dikatahui bahwa ternyata pengembangan kurikulum Seni Budaya di SD Al-Fath-BSD telah memiliki keempat landasan diatas.

1. Landasan Filsafat

Saat penulis wawancara dengan Ibu Diar selaku koordinator program kelas penjurusan seni beliau mengatakan: Landasannya, melihat dari kita, selalu kita dari dulu selalu belajar tentang seni mulai dari SD, SMP, SMA tapi tidak satupun ada satu seni yang kita kuasai. Dan seni sebetulknya lebih menekankan ke aspek skill ketimbang aspek pengetahuan karena dikehidupan nyata yang dibutuhkan dari pembelajaran seni kan justru apa yang kamu bisa, alat apa yang kamu kuasai.

Pengembangan kurikulum seni budaya di SD Al-Fath dilakukan atas dasar adanya persoalan yang menggelisahkan yang kemudian menstimulus datangnya ide atau gagasan untuk mengatasinya, apa yang dikatakan bu Diar sebetulnya adalah kritik terhadap pendidikan yang masih berpedoman pada filsafat klasik dimana tujuan dan orientasi pencapaiannya hanya penguasaan materi dan lebih menitik beratkan pada ranah intelektual kognitif belaka sehingga output yang dihasilkan pun tidak selaras dengan tuntutan zaman kekinian yang menuntut siswa menguasai suatu keahlian yang aplikatif terhadap kehidupan nyata. Oleh karena itu buah dari pengembangan kurikulum adalah terciptanya suatu kurikulum yang akomodatif terhadap tuntutan zaman namun berpijak pada kecederungan, bakat alami yang sudah ada pada diri masing masing siswa. Orientasi dari kelas penjurusan tidak lagi terpaku pada pemenuhan aspek kognitif namun bealih sepenuhnya pada pemberdayaan dan pengembangan skill dan aktualisasi diri. dengan kata lain Pendidikan seni dikelas penjurusan telah meninggalkan filsafat klasik dan beralih pada filsafat progresivisme.

2. Landasan Psikologis.

Dalam mengembangkan kurikulum, tingkat kematangan kepribadian siswa tentu harus menjadi pertimbangan tersendiri hal ini dilakukan agar pembelajaran yang dilaksanakan baik isi, metode dapat selaras dengan kadar dan kempuan peserta didik. Sebagaimana yang telah penulis jelaskan bahwa kelas penjurusan seni dilaksanakan mulai kelas IV dimana siswa pada kelas tersebut berada dalam rentang usia 10-11 tahun.

Piaget mengatakan, anak usia ini (usia 10-11), berada dalam tahapan Operasional kongkret dimana pada tahap ini anak sudah cukup matang untuk menggunakan pemikirannya. Egosentrinya berkurang dan kemampuannya dalam 
tugas-tugas konservasi sudah lebih baik hanya saja anak-anak dalam tahap ini akan mengalami kesulitan besar dalam menyelesaikan tugas-tugas logika. Oleh karena itu pelaksanaan kelas penjurusan memang lebih tepat mulai dilakukan dikelas VI, sebab pada tahapan sebelumnya, pra operasional, anak masih dalam kondisi tak siap disamping aktifitas berfikirnya belum memiliki sistem yang terorganisasikan dan cara berfikirnya masih tidak konsisiten dan tidak logis.

3. Landasan Sosiologis dan budaya.

Landasan sosiologis merupakan kajian mengenai kurikulum yang dikaitkan dengan sosial masyarakat. Sekolah berfungsi untuk mempersiapkan anak didik agar mereka dapat berperan aktif di masyarakat. Oleh karena itu, kurikulum sebagai alat dan pedoman dalam peroses pendidikan di sekolah harus relevan dengan kebutuhan dan tuntutan masyarakat ${ }^{20}$. hasil survei yang penulis lakukan menunjukan adanya kompetensi pembelajaran yang dimaksudkan untuk menguasai, mengapresiasi karya klasik maupun karya seni modern yang tengah berkembang terutama yang sedang hits di kalangan millenial seusia mereka dan usia dewasa.

4. Landasan Ilmu Pengetahuan dan Teknologi

Dewasa ini kemajuan ilmu dan teknologi sudah sampai ketaraf yang dikatakan sebagai ekspolsi (ledakan). Beraneka informasi serta teknologi modern yang digunakan terutama oleh para pelaku seni, turut mendasari kenapa pengembangan kurikulum dibidang seni ini harus dilakukan. hasil yang penulis peroleh dari proses observasi ditemukan bahwa materi, alat, metode pembelajaran dalam kelas penjurusan seni tak dapat dilepaskan dari adanya pengaruh perkembangan IPTEK yang berkembang saat ini.

\section{Pelaksanaan Fungsi manajemen}

Proses pengembangan kurikulum pelajaran seni mengikuti kerangka pikir manajemen yang meliputi perencanaan, pengorganisasian, pelaksanaan, serta pengawasan. Hal ini juga dikatakan oleh kepalas sekolah SD Al-fath melalui pernyataan berikut ini: Iya betul, perencanaan,_pengorganisasian, pengawasan serta evaluasi_tentu ada. Hal ini agar semua kegiatan yang dilaksanakan di SD Al-fath sesuai dengan tujuantujuan sekolah. tetapi perencanaan kan harus menyeluruh ya, ada program jangka panjang, jangan pendek, harian dan per week atau perminggunya, hanya saja memang belum terdokumentasi dengan baik.

1. Perencanaan

Dalam mengembangkan kurikulum, terutama model Grassroot sebagaimana dalam konteks SD Al-fath ini, keresahan guru mengenai kurikulum menjadi modal awal dan setelah ditemukan ide pengembangan barulan disusun perencanaan, analisis kebutuhan sampai dengan penyiapan dokumen-dokumen kurikulum.

20 Wina Sanjaya, Kurikulum Dan Pembelajaran: Teori Dan Praktik Pengembangan Kurikulum Tingkat Satuan Pendidikan (KTSP) (Jakarta: Prenada Media Group, 2008), 55. 
Hanya saja pengembangan kurikulum seni ini tidak dilakukan dengan cara mengembangkan komponen kurikulum seni budaya dalam pengertian menyempurnakan (improvement curriculum) melainkan menggunakan pola (curriculum contruction) dimana pengembangan kurikulum menyusun seluruh perangkat kurikulum baru mulai dari dasar-dasar kurikulum, tujuan, metode pembelajaran sampai dengan pedoman pelaksanaan yang diimplementasikan dalam format kelas penjurusan seni. Dengan begitu para pengembang dapat leluasa menentukan bagaimana kurikulum disusun dan dikembangkan. Hasil yang diperoleh adalah pemecahan ilmu bidang kesenian (sparated curriculum) yang diwujudkan melalui kelas-kelas penjurusan seni yang berjumlah 8 kelas penjurusan seni. dengan demikian, maka kurikulum seni budaya menjadi luas namun juga spesifik. ${ }^{21}$ Hanya saja dan sebagaimana telah dikatakan oleh kepada sekolah diatas bahwa pendokumentasian tidak/ belum dilaksanakan. Pendokumentasian sangat diperlukan terutama disaat para pengembang ingin meluhat kembali gagasan, arah, tujuan, prinsip-prinsip yang telah disepakati bersama dan lain sebagainya.

2. Pengorganisasian

Struktur organisasi tidak tertulis ya tapi masing-masing sudah tahu, bahwa kelas penjurusan ini bukan terpisah dari pembelajaran, tapi bagian dari pembelajaran intrakulikuler sekolah sehingga struktur organisasinya sama, yakni dibawah kepala sekolah masing masing.

Dalam konteks pengembangan kurikulum, setidaknya ada dua macam pola pengorganisasian. Pertama, pengorganisaian dalam kontek manajemen personalia dan yang kedua adalah pengorganisasian kurikulum.

a. Pengorganisasian porsonalia.

Pengorganisasian dalam kontek ini adalah keseluruhan proses pengelompokan orang-orang, tugas, wewenang serta tanggung jawab sedemikian rupa sehingga tercipta suatu organisasi yang dapat digerakkan sebagai suatu kesatuan yang utuh dan bulat dalam rangka pencapaian tujuan yang telah ditentukan sebelumnya. Pengorganisasian orang-orang, membagi tugas tanggung jawab kepada orang orang yang terlibat dimaksudkan agar tidak ada tumpang tindih wewenang, overlapping. Hal lain yang juga perlu diperhatikan adalah prinsip utama staffing yakni menempatkan orang yang tepat pada tempatnya (the right man on the right place), dan prinsip menempatkan orang yang tepat pada jabatan atau pekerjaannya (the right man behind the gun).

Dalam konteks SD Alfath-BSD, hasil observasi penulis menunjukkan pengorganisasian sudah cukup baik hanya saja masih sering terjadi overlapping seperti koordinator disuatu sekolah menjadi bawahan saat mengajar di sekolah yang lain.

b. Pengorganisasian kurikulum.

${ }^{21}$ Sukmadinata, Pengembangan Kurikulum: Teori Dan Praktik, 180. 
Dalam kontek organisasi kurikulum, S. Nasution mengatakan bahwa organisasi kurikulum adalah bentuk, pola penyusunan mata pelajaran yang akan di ajarkan kepada para peserta didik. Ada tiga model yang dijelaskan oleh S. Nasution namun model yang paling relevan dan telah digunakan oleh para pengembang kurikulum kelas penjurusan seni adalah Sparate Subject Curriculum dimana kurikulum seni yang disusun berdasarkan mata pelajaran yang terpisah-pisah, berpusat pada jenis atau cabang-cabang ilmu kesenian seperti kelas penjurusan gitar yang hanya mempelajari teknik fingering, koord, harmonisasi dalam bermain alat musik gitar. unsur seni rupa, aliran seni rupa, perspektif yang tidak diajarkan dikelas penjurusan lain selain kelas visual art dan lain sebagainya. Dengan menggunakan pola Sparate Subject Curriculum ini pembelajaran menjadi terfokus mendalam dan berkelanjutan.

3. Pelaksanaan.

Dalam sesi wawancara dengan penulis, ibu Diar mengatakan berikut ini: "Setelah disampaikan dan disetujui oleh yayasan kemudian dibuatlah uji coba/simulasi melalui Pasar Sore 22 yang dikemas dengan acara Talkshow."

Dalam konteks manajemen pengambangan kurikulum, terdapat tahapan tahapan yang harus dilalui jika kita ingin mengembangkan kurikulum salah satunya yakni melakukan ujiucoba dalam skala kecil sebelum ahirnya kurikulum dilaksanakan dilapangan hal ini sebagaimana yang di katakan oleh Omar hamalik bahwa sebelum pelaksanaan program perlu diadakan ujicoba terlebih dahulu. Uji coba ini dilakukan dalam spektum atau lingkup yang kecil. fungsi dari ujicoba ini adalah untuk menggali sebanyak mungkin informasi di lapangan guna dilakukan perbaikan, penyesuaian dan kesiapan yang perlu dilakukan sebelum kurikulum benar-benar diimplementasikan. Dengan demikian maka apa yang dilakukan oleh para pengembang kurikulum di SD Al-Fath, menurut penulis telah sesuai dengan mekanisme atau tahapan terutama dalam metode pelaksanaan.

4. Pengawasan

Pengawasan dilakukan untuk memastikan kesesuaian antara yang diharapkan dengan kenyataan di lapangan. Pengawasan juga berarti mendeteksi apa yang telah dilaksanakan dengan tujuan mengevaluasi prestasi kerja dan apabila perlu, menerapkan tindakan-tindakan korektif sehingga hasil pekerjaan sesuai dengan rencana-rencana yang telah disusun. ${ }^{23}$ Pengawasan program pengembangan kurikulum seni budaya di SD Al-Fath-BSD ini dilakukan oleh beberapa elemen sebagaimana yang dikatakan oleh kepala sekolah berikut ini: Sesuai dengan stukturnya yakni Koordinator kelas, Wakil kepsek bidang study, Kepala sekolah, baru secara keseluruhan untuk menyamakan program_antar sekolah di bawah naungan Yayasan Al-Fath_itu oleh koodinator seni.

22. Pasar sore, sebagaimana dikatakan ibu Diar adalah sejenis acara pentas seni yang dikombinasikan dengan acara bazar yang diselenggarakan secara terbuka.

23 George R Terry, Asas-Asas Menajemen, Terj. Winardi (Bandung: PT Alumni, 2006), 35. 
Mengawasi kurikulum tentu saja tidak hanya sebatas pekerjaan mengawasi gerak/aktifitas orang dan benda benda namun juga pada hal dan kecenderungan, sebab akibat yang mungkin saja tak kasat mata. Dalam konteks pengembangan kurikulum pengawasan dilakukan terhadap dua aspek. pertama pengawasan program, kedua pengawasan kurikulum.

a. Pengawasan program.

Pelaksanaan pengawasan program dalam kelas penjurusan seni adalah sebagaimana yang dikatakan oleh koordinator seni berikut ini:

"Kontroling masih menjadi pekerjaan rumah tersendiri terutama terkait guru yang flying karena kan jauh-jauh, yang dapat kita lihat ya dari absen. Tapi untuk kontrol harian ya agak berat. Maka di buat sub koordinator di setiap divisi. Sub koordinator itulah yang akan membantu mengatasi permasalahan harian seperti saat guru tidak masuk, penilaian, rapot. Kendalanya hanya itu tapi kalo komunikasi kan sekarang ada grup Wats Up".

Dari hasil observasi penulis, program kelas penjurusan seni ini diselenggarakan secara serentak di beberapa sekolah yang lokasinya berjauhan sehingga guru-guru seni sebagai pengajar/ tutor dikelas penjurusan harus flaying ke sekolah-sekolah tersebut pada hari dilaksanakannya pembelajaran di kelas penjurusan. Hal tersebut, sebagaimana dikatakan oleh koordinator seni diatas, masih menjadi hambatan/pekerjaan rumah tersendiri dalam hal kepengawasan. Disisi lain kegiatan pengawasan juga dilakukan secara kontinue, bukan hanya saat pembelajaran kelas penjurusan saja (senin dan kamis) kemudian selain itu koordinator juga diangkat di masing-masing wilayah cirende dan bsd dengan koordinator masing masing. koordinator selain berfungsi sebagai pengawas juga berfungsi sebagai orang yang bergerak aktif untuk membantu apabila muncul permasalahan, (problem solver), baik permasalahan teknis maupun non teknis yang bersifat harian. Komunikasi antar wilayah dalam fungsi kepengawasan ini juga dilakukan menggunakan media online yakni melalui aplikasi Wats up dan juga CCTV.

b. Pengawasan kurikulum.

Kepala sekolah mengatakan "Pengawasan secara keseluruhan dan untuk menyamakan program_antar sekolah di bawah naungan Yayasan Al-Fath itu oleh koodinator seni".

Apa yang disampaikan oleh kepala sekolah tersebut mengandung pengertian bahwa pengawasan yang dilakukan terhadap komponen kurikulum secara keseluruhan yakni apakah hal-hal tersebut sesuai dengan apa yang sudah ditetapkan bersama dalam perencanaan ataukah harus ada perbaikan dan penyesuaian-penyesuaian dan apakah antara SD, SMP Al-Fath-BSD sudah ada kesamaan dengan SD, SMP Al-Fath-Cirendeu. Namun pengawasan kurikulum masih menjadi pekerjaan rumah tersendiri sebagaimana yang dikatakan oleh kepala sekoplah berikut ini: Ini yang belum termanage, karna memang harusnya 
pengawasan ada instrumennya yang dirumuskan bersama, standar apa yang harus dimiliki oleh guru seni, semuanya mulai dari pengajaran persiapan, Tidak ada supervisi, walaupun akan dilakukan mulai tahun ini.

\section{Hambatan-hambatan}

Dalam pelaksanaan program kelas penjurusan seni, ditemukan beberapa kendala atau hambatan sebagaimana yang dikatakan kepala sekolah berikut ini: "Adapun kendala yang dihadapi dalam program ini secara umum: Guru yang mengajar dibeberapa tempat, juga beberapa guru yang statusnya partimer, itu cukup menyulitkan kita _terutama_ketika kita membutuhkan mereka untuk kegiatan sekolah diluar jam kerja, seperti mau latihan diluar jam penjurusan tidak bisa dilakukan disebabkan gurunya tidak hadir. kemudian juga dokumen-dokumen kelengkapan pengajarannya tidak terdokumentasi, kedisiplinan baik secara administrasi maupun kehadiran, Di samping itu kita juga masih terkendala dengan alat, sarana dan prasarana terkadang ada beberapa alat yang tidak memenuhi dan ruang yang belum terpenuhi misalnya kelas Teater idealnya tidak dikelas tapi diruangan khusus yang disitu ada cermin, kelas Choir/Vocal juga sama, harusnya ada ruangan khusus yang kedap suara sehingga tidak mengganggu kelas lain. Kelas Visual art pun demikian harusnya ada ruangan khusus, sehingga bisa bebas berekplorasi untuk melaksanakan pembelajaran, karena harus pakai cat dls".

Dari apa yang diutarakan oleh kepala sekolah di atas, ada beberapa poin yang dapat disimpulkan terkait dengan hambatan-hambatan atau kendala yang dihadapi dalam melaksanakan program kelas penjurusan seni, yaitu sebagai berikut:

1. Guru yang mengajar di beberapa tempat.

Sebagaimana telah dikatakan bahwa SD Al-Fath-BSD bukanlah satu-satunya sekolah yang menyelenggarakan kelas penjurusan seni, diketahui setidaknya ada tiga sekolah lainnya yang berada di naungan yayasan Al-Fath Bina Insan Sakina yang juga secara seragam menyelenggarakan kelas penjurusan seni ini. Sementara guru yang mengajar diseluruh kelas penjursan itu hanya 12 orang yang tidak semuanya berstatus sebagai guru tetap yayasan. Hal tersebut diakui oleh kepala sekolah menjadi kendala tersendiri.

Guru merupakan komponen utama, unsur yang tak bisa dipisahkan dalam konteks manajemen pengembangan kurikulum. Keberadaan, jumlah, kualitas guru, sangat mempegaruhi kualitas proses dan hasil pembelajaran di sekolah. Dalam kontek SD ALfath bsd, kekurangan guru seni menjadikan guru yang ada "flying". Kendala yang dihadapi oleh para guru dan juga menjadi kendala dalam menjalankan fungsi kepengawassan_adalah jarak dan kesiapan menempuh medan yang jauh di samping juga konsentrasi guru harus terbagi terutama disaat akan dilakukan pementasan secara serempak atau berdekatan waktunya.

2. Dokumen kelengkapan pengajaran tidak terdokumentasi.

Dokumen pembelajaran merupakan perangkat yang harus dimiliki oleh setiap guru. Seorang guru yang profesional sudah tentu memiliki kecakapan untuk 
membuat dokumen-dokumen pembelajaran dan telah mempersiapkannya sebelum pelajaran dimulai. Dokumen-dokumen tersebut baik berupa RPP, Silabus, KKM yang tentunya sangat diperlukan baik oleh guru itu sendiri, kepala sekolah serta bagi para siswa sebagai objek pendidikan. tanpa dokumentasi yang baik tentu akan menjadi persoalan tersendiri tatkala dokumen itu dibutuhkan baik oleh guru itu sendiri maupun kepala sekolah khususnya saat akan diadakan akreditasi sekolah.

3. Kedisiplinan baik secara administrasi maupun kehadiran.

Seorang guru dapat dikatakan memiliki disiplin kerja yang tinggi jika yang bersangkutan konsekuen, bertanggung jawab atas tugas yang diamanahkan kepadanya. Kedisiplinan guru sangat diperlukan bukan hanya bagi guru itu sendiri namun bagi semua elemen yang ada disekolah karena dalam perspektif manajemen disekolah guru merupakan unsur yang sangat vital dalam proses pembelajaran, keterlambatan kehadiran tentu akan mengganggu kelancaran dalam proses pembelajaran di sekolah.

Akan tetapi guru bukanlah manusia yang sempurna, maka pembinaan disiplin kerja tetap diperlukan bagi mereka, hal ini berarti merupakan upaya yang harus dilakukan oleh kepala sekolah kepada bawahannya yakni menumbuh kembangkan, memajukan sikap dan kualitas pekerjaannya agar semakin meningkat, sehingga kualitas pekerjaannya pun meningkat. ${ }^{24}$

Dalam menegakkan disiplin bukanlah ancaman atau kekerasan yang dilakukan, yang diperlukan adalah ketegasan. Ketegasan dan keteguhan dalam melaksanakan peraturan merupakan modal utama dan syarat mutlak untuk mewujudkan disiplin. Selain itu perlu diperhatikan bahwa pendekatan kognitif yang bersifat menghukum biasanya mempunyai berbagai pengaruh samping yang merugikan seperti hubungan emosional yang terganggu, absensi meningkat, kelesuan dan ketakutan.

4. Beberapa alat yang tidak memenuhi dan ruang yang belum terpenuhi.

Tak dapat dipungkiri bahwa alat atau sarana prasarana merupakan salah satu unsur pokok yang harus dipenuhi demi terwujudnya manajemen yang baik. Manullang menyebutkan bahwa unsur-unsur manajemen tersebut terdiri dari manusia, material, mesin, metode, money dan markets. Setiap unsur-unsur tersebut memiliki peranan bagi suatu manajemen dimana ia merupakan alat untuk mencapai tujuan.

\section{PENUTUP}

\section{Simpulan}

Pengembangan kurikulum seni budaya yang diaktualisasikan dalam bentuk kelas penjurusan seni merupakan praktik baik yang perlu dilestarikan sepanjang

${ }^{24}$ Ahmad Susanto, Manajemen Peningkatan Kinerja Guru: Konsep, Strategi Dan Implementasinya (Jakarta: Kencana, 2016), 104. 
menjadikan pembelajaran itu efektif dan berdayaguna secara optimal dalam menumbuhkan multiple intelgensi para sisiwa. Menejemen pengembangan kurikulum seni budaya yang dilaksanakan oleh SD Al-Fath BSD sudah baik namun karena manajemen pengembangan kurikulum tersebut tidak/belum dilakukan secara optimal; seperti dalam menjalankan fungsi perencanaan, pengawasan dan juga unsur manajemen yang belum sepenuhnya terpenuhi maka menimbulkan hambatan atau problematika tersendiri yang tentunya dapat mengganggu proses kegiatan belajar mengajar itu sendiri. Oleh karenanya, selain menjalankan fungsi manajemen dengan baik, Unsur-unsur manajemen pun harus dipenuhi karena pada dasarnya dalam dinamika manajemen segala sesuatunya berlaku secara dialektik, saling bergantung satu sama lainnya. Funsi manajemen yang tidak sungguh-sungguh dilakukan atau suatu unsur manajemen yang tidak dipenuhi sedikit banyak akan berdampak pada lajunya pelaksanaan dan kualitas hasil.

\section{Saran}

Upaya-upaya yang dapat dilakukan untuk meningkatkan manajemen pengembangan kruikulum seni budaya dan Keterampilan sangat beragam dan bisa jadi akan beragam persepsi tergantung siapa pengamatnya. Dalam konteks SD Alfath-BSD, selain menjalankan fungsi manajemen dengan baik, pemenuhan terhadap kebutuhan pelaksanaan pembelajaran (unsur manajemen) juga harus dipenuhi. Inovasi merupakan nafas perubahan yang tak dapat dielakkan. Dalam menegakkan disiplin bukanlah ancaman atau kekerasan yang diutamakan, yang diperlukan adalah ketegasan. Ketegasan dan keteguhan dalam melaksanakan peraturan merupakan modal utama dan syarat mutlak untuk mewujudkan disiplin.

Pembinaan disiplin kerja merupakan upaya yang dilakukan oleh seorang pemimpin kepada bawahannya untuk menumbuh kembangkan, memajukan sikap dan kualitas pekerjaannya semakin meningkat, sehingga kualitas pekerjaannya pun meningkat. ${ }^{25}$ Pendekatan kognitif yang bersifat menghukum biasanya mempunyai berbagai pengaruh samping yang merugikan seperti hubungan emosional yang terganggu, absensi meningkat, kelesuan dan ketakutan.

Kepala sekolah sebagai pimpinan harus mampu menumbuhkan disiplin kerja guru, Guru juga harus mempunyai kesadaran akan pentingnya sikap disiplin baik dalam kehadiran maupun dalam melengkapi administrasi pengajaran. Dari realitas yang ada di lapangan diketahui bahwa rendahnya produktifitas tenaga pendidik dan kependiidkan disekolah, baik dalam mengikuti aturan dan tata tertib sekolah maupun dalam melakukan pekerjaansangat erat kaitannya dengan disiplin.

Oleh karena itu, dalam menumbuhkan kepala sekolah profesional dalam paradigma baru pendidikan disekolah diperlukan adanya peningkatan disiplin untuk menciptakan iklim sekolah yang lebih kondusif dan dapat memotifasi kerja, serta dapat

25 Susanto, 104.Ahmad Susanto, Manajemen peningkatan kinerja guru, hal. 104 . 
menciptakan budaya kerja dan budaya disiplin para tenaga pendidik dan kependidikan dalam melakukan tugas sekolah. ${ }^{26}$

Terimakasih kepada seluruh pihak yang turut membantu penelitian ini; Yayasan Al-Fath Bina Insan Sakina, Kepala sekolah dan Koordinator seni SD Al-FathBSD, seluruh guru-guru seni Al-Fath yang bersedia meluangkan waktunya untuk keperluan penelitian ini. Selanjutnya penelitian ini tentu masih banyak kekurangan, saran konstruktif tentu sangat penulis harapkan demi perbaikan selanjutnya.

\section{E. DAFTAR PUSTAKA}

Arifin, Zainal. Pengembangan Manajemen Mutu Kurikulum Pendidikan Islam. Bandung: Remaja Rosdakarya, 2012.

Arikunto, Suharsimi. Prosedur Penelitian Suatu Pendekatan Praktik. Jakarta: Rineka Cipta, 2013.

Hamalik, Oemar. Dasar-Dasar Pengembangan Kurikulum. Bandung: Remaja Rosdakarya, 2013.

Herawati, Evi. "Hamalik, Oemar. Dasar-Dasar Pengembangan Kurikulum.Bandung: PT. Remaja Rosdakarya, 2013. Herawati, Evi. "Pengembangan Kurikulum Pendidikan Agama Islam Di Sekolah Alam Studi Kasus Di School of Universe." UIN Syarif Hidayatullah, 2009.

Hernawaty. Metode Montessori, Pendidikan Karakter Yang Mengembangkan Potensi Anak. Surabaya: Garuda Mas Sejahtera, 2015.

Lismina. Pengembangan Kurikulum. Ponorogo: Uwais Inspirasi Indonesia, 2017.

Pidato kenegaraan Menteri Pendidian dan kebudayaan Republik Indonesia (n.d.). https://www.kemdikbud.go.id/main/blog/2019/08/pidato-mendikbud-padaperingatan-hut-ke74-republik-indonesia.

Purwatiningsih. "Sumber Belajar Penunjang PLPG 2007 Mata Pelajaran Seni Budaya," 2017.

Sanjaya, Wina. Kurikulum Dan Pembelajaran: Teori Dan Praktik Pengembangan Kurikulum Tingkat Satuan Pendidikan (KTSP). Jakarta: Prenada Media Group, 2008.

Sarnoto, Ahmad Zain. "Paradigma Pendidikan Humanistik Dalam Pendidikan Berbasis $\mathrm{Al}$ Quran." Jurnal MADANI Institute Volume 7 N (2018).

_- _. "Sumber Daya Manusia Dalam Pendidikan Islam." Jurnal MADANI Institute Volume $6 \mathrm{~N}$ (2017).

Soetopo, Soengkowo. "Pendidikan Seni Di Sekolah Dasar.” Jurnal Inovasi Sekolah Dasar, Vol. 2, No (2015).

Sugiyono. Metodologi Penelitian Pendidikan Pendekatan Kuantitatif, Kualitatif, Dan R\&D. Kelima. Bandung: Alfabeta, 2008.

Sukmadinata, Nana Syaodih. Pengembangan Kurikulum: Teori Dan Praktik. Bandung: Remaja Rosdakarya, 2006.

\footnotetext{
26 Susanto, 104-5.
} 
Susanto, Ahmad. Manajemen Peningkatan Kinerja Guru: Konsep, Strategi Dan Implementasinya. Jakarta: Kencana, 2016.

Susilana, Rudi. Bahan Ajar Konsep Kurikulum. Bandung: Tim Jurusan Kurikulum dan Teknologi Pendidikan FIP-UPI, n.d.

Terry, George R. Asas-Asas Menajemen, Terj. Winardi. Bandung: PT Alumni, 2006.

Tilaar, H.A.R. Pengembangan Kreativitas Dan Entrepreneurship Dalam Pendidikan Nasional. Jakarta: PT Kompas Media Nusantara, 2012.

Wahyudin, Dinn. Manajemen Kurikulum. Bandung: Remaja Rosdakarya, 2014. 